\title{
MEASUREMENT OF THE DUCTILE TO BRITTLE TRANSITION TEMPERATURE FOR WASTE TANK COOLING COILS (U)
}

\author{
B. J. Wiersma
}

\begin{tabular}{c} 
UNCLASSIFIED \\
DOES NOT CONTAIN \\
UNCLASSIFIED CONTROLLED NUCLEAR INFORMATION \\
D. Themm Ralui \\
Reviewing Orficlal and Authorized Derivative Classifier \\
Date: October 21,1992 \\
\hline
\end{tabular}

Westinghouse Savannah River Company Savannah River Site Aiken, SC 29808

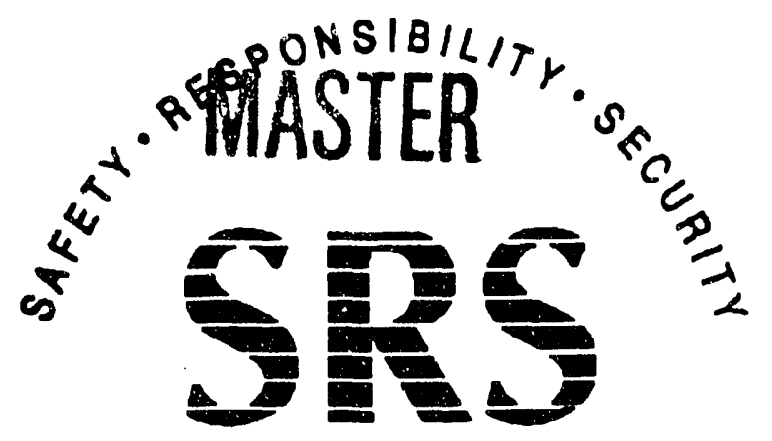

\section{SAVANNAH RIVER SITE}


WSRC-TR-92-444 (U)

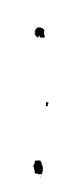

THIS PAGE INTENTIONALLY LEFT BLANK 


\section{CONTENTS}

SUMMARY

INTRODUCTION 1

EXPERIMENTAL PROCEDURE 2

Test Materials 2

Charpy Impact Tests 3

Metallography 4

EXPERIMENTAL RESULTS 5

Charpy Impact Tests 5

Metallography $\quad 6$

DISCUSSION 7

Charpy Impact Tests 7

Metallography 11

CONCLUSIONS

FUTURE WORK 12

$\begin{array}{ll}\text { REFERENCES } & 12\end{array}$

TABLES

FIGURES 


\section{LIST OF TABLES}

Page

Table I Composition of A106 Cooling Coil And Reference Materials

Table II Physical Properties of A106 Cooling Coil And Reference Materials

Table III Ductile-Brittle Transition Temperature, Upper Shelf Energy And Lowest Service Metal Temperature Results From Charpy Impact Tests

Table IV Summary Of Microstructural Features

\section{LIST OF FIGURES}

Tigure 1. Schematic Drawings of a) Cooling Coil Pipe Showing Orientation Directions And b) The Orientation Of The Charpy Bar In The Cooling Coil.

Figure 2. Schematic Diagram Of Charpy Impact Data And Determination 16 Of The Ductile To Brittle Transition Temperature (DBTT).

Figure 3. ASTM Dimensions For Charpy Impact Specimens For

a) Length Of Specimen And Notch Acuity, b) Sub-Size,

c) MEA and d) Full-Size.

Figure 4t. Load vs. Time Data During Charpy Impact Test On Tank 38

Outlet Specimens At a) $-175^{\circ} \mathrm{F}, \mathrm{b}$ ) $-100^{\circ} \mathrm{F}$, and c) $50^{\circ} \mathrm{F}$.

Figure 5. Energy vs. Temperature For Full-Size And Sub-Size

Reference Specimens.

Figure 6. Energy v8. Temperature For Sub-Size Tank And Reference

Figure 7. Charpy Specimen Fracture Surface Of Specimen From

Figure 8. Charpy Specimen Fracture Surface Of Specimen From

Figure 8. LEFM Analysis For A Circumferential Flaw Subjected 
WSRC-TR-92-444 (U)

APPROVALS

Ounce of Derma

Date:

$10-21-92$

B. J. Wiersma, AUTHOR

Materials Applications \& Corrosion Technology Group

MATERIALS TECHNOLOGY SECTION

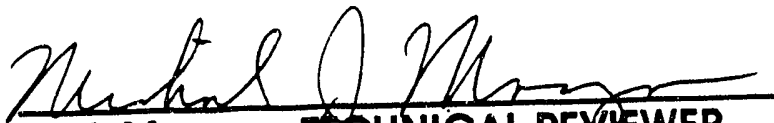

Date: $10-22-92$

M. J. Morgan, CHNICAL REVEWER

Materials Compatibility \& Joining Technology Group

MATERIALS TECHNOLOGY SECTION

\& 14

Date: $10-22-92$

G. G. Metz, TE G FAIICAL REVIEWER

Engineering Development Group

MATERIALS TECHNOLOGY SECTION

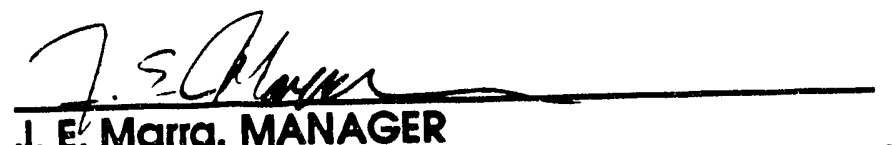

Date: $10-23-92$

Materials Applications \& Corrosion Technology Group

MATERIALS TECHNOLOGY SECTION

T. L. CapelettI, MANAGER

Date: $11 / 9 / 92$

MATERIALS TECHNOLOGY SECTION

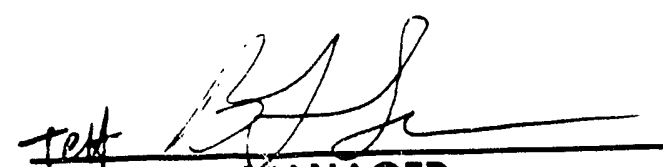

Date: $11-6-92$

B. L. Lewis, MANAGER

HLW Cognizant Engineering WASTE MANAGEMENT ENGINEERING

$v$ 


\title{
Measurement of the Ductile to Brittle Transition Temperature for Waste Tank Coolins Coils (U)
}

\author{
Bruce J. Wiersma \\ Westinghouse Savannah River Company \\ Savannah River Site \\ Aiken, SC 29808
}

\section{SUMMARY}

Charpy impact tests were conducted on ASTM A106 carbon steel archived from SRS waste tanks to determine the susceptibility of the cooling coils to brittle fracture during a seismic event. The highest ductile to brittle transition temperature measured was $-5^{\circ} \mathrm{F}$ and, with the addition of a $30^{\circ} \mathrm{F}$ safety factor, the minimum safe operating temperature was determined to be $25^{\circ} \mathrm{F}$. Calculations also showed that a pre-existing circumferential flaw that is 2.2 " long would be necessary to initiate brittle fracture of the pipe. These results demonstrate that the pipes will not be susceptible to brittle fracture if the cooling water inlet temperature is lowered to $50^{\circ} \mathrm{F}$.

Visual observation of the inner and outer walls of the pipe showed no localized attack or significant wall thinning. A 100-200 micron zinc coating is probably the reason for the lack of corrosion. A build-up of zinc slag occurred at pipe fittings where the weld had burned through. Although no attack was observed, the slag created several crevices which have the potential to trap the chromated water and initiate localized attack.

\section{INT RODUCTION}

High level radioactive waste produced in the SRS separations areas will be processed in Type III carbon steel tanks. The processed waste will be fed to the Defense Waste Processing Facility (DWPF) for vitrification. Type III waste tanks are equipped with cooling coils to remove the decay heat generated by radioactive wastes. Cooling is achieved by running chromate inhibited water at a temperature of approximately $60^{\circ} \mathrm{F}\left(15^{\circ} \mathrm{C}\right)$ through the coils. The coils are $2^{\prime \prime}$ ID, schedule 40 pipes 
fabricated from either ASTM A53 (A53) or ASTM A 106 (A 106) carbon steel.

Two issues regarding the cooling coils have recently been raised. Waste Management initially proposed to increase the cooling capacity in the tank by installing chillers that would decrease the inlet cooling water temperature to $50^{\circ} \mathrm{F}\left(10^{\circ} \mathrm{C}\right)$. The possibility of brittle fracture of the cooling coil pipe during a seismic event at this lower temperature became a concern. The toughness, or resistance to unstable crack growth, of carbon steels is very temperature dependent. At low temperatures, carbon steels subjected to a significant load may fail rapidly due to brittle fracture. As the temperature increases, the material becomes tougher and will requre a much higher load to induce ductile overload failure. Thus, there is a transition temperature range above which the cooling coils should be operated at in order to assure adequate safety. Ondrejcin has represented this transition range as a single temperature referred to as the nil ductility transition tem perature (NDTT). 1 In this report, this temperature is defined as the ductile to brittle transition temperature (DBTT) to reflect the transition between two different failure modes (i.e., ductile and brittle).

Fracture analysis calculations were made to assess the minimum service temperature which the cooling coils could operate at without being susceptible to brittle fracture. ${ }^{2}$ A DBTT of $-20^{\circ} \mathrm{F}\left(-29^{\circ} \mathrm{C}\right)$ was assumed and the lowest service metal temperature (LST) was calculated to be $10^{\circ} \mathrm{F}\left(-12^{\circ} \mathrm{C}\right)$. Ondrejcin and Mertzl questioned this LST based on studies performed on A53 carbon steel by Materials Engineering Associates (MEA). The A53 material for the MEA tests was obtained from SRS reactor piping. The DBTT was $40^{\circ} \mathrm{F}\left(4^{\circ} \mathrm{C}\right)$ which would give a LST of $70^{\circ} \mathrm{F}$ $\left(21^{\circ} \mathrm{C}\right)$. Since this temperature is above the current and proposed operating temperature, impact tests to experimentally determine the DBTT were performed. In addition, metallography was performed on the impact specimens to investigate the effect of the material's microstructure on the DBTT and the fracture mode. Finally, calculations which assess the structural integrity of the cooling coils were performed.

A second issue relates to the recent discoveries of cooling coil failures in the Type III tanks. Tank 48, the tank where the In-Tank Precipitation (ITP) will occur, has experienced failures in approximately $25 \%$ of its coils. Investigations in the past indicated that cooling coil failures occurred in Type II tanks after sludge removal due to pitting corrosion. ${ }^{3}$ 
Since sludge removal was not performed in the Type III tanks, the precise failure mecharism is unknown. Visual and microscopic observations of archived A 106 material were made to evaluate possible leak sites and hence failure mechanisms.

\section{EXPERIMENTAL PROCEDURE}

\section{Test Materials}

Charpy specimens were prepared from actual cooling coil pipes (A106) which were removed from the valve houses of Tanks 38,40 , and 48 . These coils had failed and were blanked off to prevent cooling water flow. A sketch of the cooling coil section showing the orientation of the specimen is shown in Figure 1. The composition and physical properties of the A 106 material used for the cooiing coils in Tank 38-43 were obtained from Certified Mill Test Reports (CMTR) and are shown in Tables 1 and 2. Based on these specifications the material is classified as A 106 Grade B. The tables show several different neats of material with variations in composition and physical properties. Thus, variation in the measured transition temperature would be expected.

Specimens fabricated from a "reference heat" of A 106 Grade B material were purchased from Metal Samples, Inc. so that the effect of specimen size and composition could be investigated. Compositions and physical properties for these specimens are also shown in Table 1.

\section{Charpy Impact Tests}

Charpy impact testing of notched specimens at low and high temperatures is performed to predict the susceptibility of a material to brittle fracture. The principal measurement from the Charpy impact test is the energy absorbed in fracturing the specimen. The energy required to fracture the specimen is related to the likelihood of brittle or ductile fracture of a material at a given temperature (see Figure 2). The low fracture energies, referred to as lower shelf energies (LSE), at low temperatures are associated with brittle fracture. The upper shelf energies (USE) at higher temperatures, on the other hand, are associated with ductile failure. A conservative estimate of the DBTT is the temperature at which the impact energy is one half the average USE. 
The Charpy impact tests were performed at Virginia Polytechnic Institute (VPI) on a Tinius Olsen Model 84 Universal Impact Tester (pendulum type) following ASTM Standard E23-91. The machine consisted of a pendulum, an anvil to hold the specimen, and a striker or tup which impacts the specimen. The VPI machine was equipped with an instrumented tup to accurately determine the fracture energy. The tests were performed at temperatures between the boiling point of liquid nitrogen, $-324^{\circ} \mathrm{F}\left(-198^{\circ} \mathrm{C}\right)$, and the boiling point of water, $212^{\circ} \mathrm{F}$ $\left(100^{\circ} \mathrm{C}\right)$. Temperatures were measured by thermocouples spot welded to the specimens.

Since the cooling coil walls are only $0.154^{\prime \prime}$ thick, sub-size specimens were machined from the coils to a thickness of $0.118^{\prime \prime}$. The dimensions of the sub-size specimens, for the se and the MEA experiments, and fullsize specimens are shown in Figure 3. Full-size and sub-size specimens of the reference heat of A 106 were tested for comparison. The samples were oriented so that the crack propagated in the short transverse direction across the short transverse-long transverse plane. This orientation simulates a circumferential crack on the cooling coil pipe.

The machine was equipped with the DYNATUP data acquisition system which received the measured impact energies and analyzed the data. Load vs. time data is collected during the impact tests. Impact time is indicated by the sudden rise in the load, while fracture is detected by a sharp decrease in the load. The impact energy is calculated by integrating the area beneath the load vs. time plot and multiplying by the average velocity of the hammer during impact. Figure 4 shows plots of the load vs. time (dark lines) and energy vs. time (light lines) at low, transition, and upper shelf temperatures for specimens from the tank 38 outlet piping. Figure 4 a demonstrates that at low temperatures the material fractures in the elastic regime prior to the yield point. The small loads and short impact times produce the very low energies characteristic of brittle fracture. At very low temperatures the impact energy is independent of temperature. As the test temperature increases, plastic deformation begins to occur at the crack tip. The load vs. time curve demonstrates a definite yield point and a plastic regime prior to fracture of the specimen (Figures $4 b$ and $4 c$ ). The longer the time between yielding and fracture the higher the impact energy value for fracture. At high temperatures, the impact energy again becomes independent of temperature which is indicative of ductile failure.In addition to the fracture energy determination, the fracture surfaces were examined for indications of brittle or ductile fracture. 


\section{Metallography}

Visual observations were made of the outer and inner walls of the archived pipes. For microscopic studies, representative samples of cooling coil material were sectioned and mounted in the longitudinal, long transverse, and short transverse orientations. They were ground, polished, and then etched with nital to reveal the microstructure. Optical and scanning electron microscopy (SEM) were performed to examine the microstructure of the samples. An Olympus Cue-2 Image Analyzer was used to estimate the percent pearlite and the volume percent (vol\%) of inclusions present in the material. Energy dispersive spectroscopy (EDS) and X-ray florescence (XRF) were conducted to determine material and corrosion product compositions.

The procedures and results of the Charpy impact tests and the metallography are detailed in laboratory notebook WSRC-NB-92-130.

\section{EXPERIMENTAL RESULTS}

\section{Charpy Impact Tests}

Figure 5 compares the impact energy vs. temperature results for the full-size reference heat specimens with the sub-size reference heat specimens. The data were normalized with respect to the initial fracture area of the specimen. Normalization permitted both sets of data to be shown on the same plot. The sub-size specimens demonstrated a significantly lower DBTT, $-45^{\circ} \mathrm{F}\left(-43^{\circ} \mathrm{C}\right)$ to $50^{\circ} \mathrm{F}\left(10^{\circ} \mathrm{C}\right)$, and USE, $272 \mathrm{ft}-1 \mathrm{bs} / \mathrm{in}^{2}$ to $447 \mathrm{ft}-\mathrm{lbs} / \mathrm{in}^{2}$, than the full-size specimens.

Figure 6 shows the impact energy vs. temperature plots for the cooling coil specimens and the sub-size reference heat specimens. Table 3 includes the DBTT and the upper shelf energy values for the tests. The DBTT ranged from a low value of $-70^{\circ} \mathrm{F}\left(-57^{\circ} \mathrm{C}\right)$ for the Tank 40 material to $-5^{\circ} \mathrm{F}\left(-21^{\circ} \mathrm{C}\right)$ for the Tank $48 \mathrm{material}$. The upper shelf energy ranged from $333 \mathrm{ft}-\mathrm{lbs} / \mathrm{in}^{2}$ for the Tank $40 \mathrm{material}$ to $277 \mathrm{ft}-\mathrm{lbs} / \mathrm{in}^{2}$ for the Tank 38 outlet material.

SEM micrographs of the impact fracture surfaces confirmed the DBTT's estimated by the energy vs. temperature curves. The micrographs were also studied to determine whether transgranular cleavage occurred 
during brittle fracture and how the pearlite and inclusions in the material influenced the dimple size during ductile failure.

Figure 7 is a micrograph of the fracture surface of a specimen taken from Tank 38 inlet and tested at a temperature of $-100^{\circ} \mathrm{F}\left(-73^{\circ} \mathrm{C}\right)$. The fracture surface exhibited greater than $90 \%$ brittle cleavage. There were small areas of dimpled rupture which would classify the fracture mode as quasi-cleavage. The facets on the fracture surface were approximately 5-20 microns. These values are similar to ferrite grain sizes which were between 10-30 microns. The facets were produced by changes in the orientation of the ferrite grain boundaries which impede the propagation of cleavage cracks. "Feather" and "river" patterns were observed on the facets. These markings and the facet sizes are indicative of transgranular cleavage fracture.

Figure 8 is a micrograph of the fracture surface of a specimen taken from Tank 38 inlet and tested at a temperature of $25^{\circ} \mathrm{F}\left(-4^{\circ} \mathrm{C}\right)$. In this case the fracture surface demonstrated $100 \%$ dimpled rupture. A distribution of large elongated dimples and smaller circular dimples was observed. The elongated dimples were particularly prevalent in the sub-size specimens where some of the fracture occurred by tearing. The smaller circular dimples were probably associated with the more brittle pearlite phase or a higher inclusion density.

\section{Metallography}

Visual observations of the A 106 material were made as the material was being sectioned and machined to prepare the Charpy impact specimens. The outside of the pipe had a dull gray appearance and indicated no form of degradation. Although the walls were covered with gray, red, and black colored corrosion product, the inside of the pipe did not have any evidence of localized attack or excessive wall thinning.

The machining of the rectangular Charpy impact specimens proved to be a difficult task. Frequently, the outer edge of the specimen would flake off during the machining, leaving an uneven surface. This edge had a duller gray appearance than the majority of the specimen surface area, indicating that the A 106 material was coated with another material. Light microscopy, SEM, and EDS were used to evaluate this coating. 
Microscopy revealed that the coating was a 100-200 micron thick layer of zinc. Both the inner and outer walls of the pipe were coated with zinc. This observation was verified when the gray corrosion product on the inside of the surface was identified by XRF to contain zinc. The presence of the zinc layer indicated that the pipes were galvanized.

Observations of the welds at pipe fittings for the pressure relief valves and gages revealed interesting features. A $5-10 \mathrm{~mm}$ high build-up of slag completely encircled the pipe fitting area where the weld had burned through. The slag had a rough, uneven appearance which appeared to be degraded. The slag was determined by XRF to be primarily zinc. In the region next to the slag, the coating was chipped in several locations. Two weids were cross-sectioned and examined, however, no attack was observed beneath or next to the slag area.

\section{DISCUSSION}

\section{Charpy Impact Tests}

During the impact tests incomplete fracture of the sub-size specimens frequently occurred, particular!y at the higher temperatures. This result suggests that the observed USE is lower than the actual USE. Although the USE would be shifted upward in the plot, there would be no significant shift in the DBTT. Therefore, the results of these tests can be used to determine the minimum service temperature for the coils.

The results from the reference heat tests on sub-and full-size specimens demonstrate that mechanical as well as metallurgical variables influence the DBTT. Qualitatively the energy vs. temperature curves obtained for sub-and full-size specimens are similar in appearance. However, quantitatively the measured energy and transition temperature are lower for the sub-size specimens than the full-size specimens. Normalization by factors such as the fracture area are frequently attempted in order to gain quantitative agreement between the results for sub- and full-size specimens. Although overlap of the curves may occur in one region of the curve (e.g.. lower shelf energies) the curve will seldom overlap in other regions. 4 This lack of agreement occurs because fracture processes are sensitive to stress state and, hence, specimen size.

The sub-size specimens have a larger span to width ratio than the fullsize specimens. The smaller width reduces the constraint at the notch 
tip in the direction perpendicular to the strip plane (i.e., the stress state approaches plane stress). For the full-size specimens there is sufficient constraint at the notch tip so that the stress state becomes triaxial and approaches the plane strain stress state. Transition temperature shifts between samples of similar size are well documented in the literature. 5 Depending on the material, similar decreases in the specimen width may produce DBTT shifts berween $150-200^{\circ} \mathrm{F}$.

A decision on which DBTT to apply to the cooling coil pipes was necessary. According to Cotton, ${ }^{6}$ three criteria must be met in order to apply Charpy data to service conditions: 1) specimen has similar thickness as the pipe wall, 2) specimen has experienced same heat treatment or weld condition, and 3 ) a sharp crack is the initiating defect. The sub-size specimens clearly meet these criteria better than the full-size specimens. The DBTT that Ondrejcin and Mertz employed was based on data from specimens which were nearly three times thicker than the cooling water pipe. Therefore, DBTT data from the subsize specimens should be applied to the cooling coil pipes.

There is a wide distribution of DBTT's for the sub-size specimens $\left(-70^{\circ} \mathrm{F}\right.$ to $-5^{\circ} \mathrm{F}$ ). However, the DBTT for the reference specimen falls within this range, indicating that the material toughness of the cooling coil has not degraded with service and that original material properties can be used for integrity analysis. The microstructure and composition of the A 106 material are responsible for the ranges observed in the DBTT and USE. The literature indicates that for a carbon steel with stringer inclusions an increase in pearlite from 12 to $25 \%$ increases the DBTT by approximately $50^{\circ} \mathrm{F}$. For the same increase in pearlite a $38 \%$ decrease in the USE would be observed. 7 An increase of 1 ASTM unit in the ferrite grain size will decrease the DBTT by $30^{\circ} \mathrm{F} .8$ An increase in the vol\% of sulfide inclusion stringers from 0.033 to 0.079 increased the DBTT by $79^{\circ} \mathrm{F}$ and reduced the USE by $77 \% .^{7}$ A greater density of inclusions also provides more sites for nucleation of microvoids and, hence, smaller dimples during ductile failure. These metallurgical features were investigated and then correlated with the results from the Charpy impact tests.

A summary of these microstructural features is shown in Table 4 . The specimens have approximately the same pearlite content $(22 \%)$ except for the Tank 40 specimens $(15 \%)$. This result would suggest that the DBTT for Tank 40 specimens would be significantly less than that for the other specimens. The ASTM grain size numbers ranged from 6.5 - 
9.5 with Tank 40 having the largest ASTM grain size number or smallest grain size. From this data. Tank 40 would have the lowest DBTT, followed by the specimens from the remaining tanks and the reference material respectively. The inclusions observed were primarily $\mathrm{MnS}$ stringers aligned in the longitudinal direction. The vol\% of inclusions ranged from 0.004 to 0.0629 . Based on this result, specimens from Tank 48 and Tank 38 inlet would have the lowest DBTT, followed by Tank 40 and then Tank 38 outlet and the reference material. Taking all these microstructural features into consideration, Tank 40 would be expected to have the lowest DBTT and highest USE. The remaining tank specimens would be predicted to have approximately the same DBTT, while the reference material should have the highest.

The DBTT results correlated well with the metallographic observations. As was predicted by the metallography studies, the specimens from Tank 40 had a significantly lower DBTT than the other tank specimens. The smaller ferrite grain size and lower pearlite percentage were the most influential microstructural features. Differences between the DBTT for Tanks 38 and 48 are within the scatter of the data. The similarity of the reference material DBTT to the majority of the tank specimens indicates that pearlite percentage is the most influential microstructural feature.

Application of the Charpy impact test data to actual service is not a straight forward procedure. There are two reasons for these difficulties. First, in many instances the Charpy specimen thickness is different than the wall thickness of the pipe or vessel of interest. The use of sub-size specimens, which have a similar thickness as the pipe wall, reduced this concern somewhat. The second factor is that correlations between energy values obtained from impact tests and stresses necessary for structural integrity analysis are empirical and material dependent. Correlations between the impact energy and the stress intensity factor, $K_{I c}$, are examples of empirical, material dependent relationships. Difficulties may also arise in equating the DBTT from Charpy impact tests (which is based on an energy value) with the DBTT obtained from the drop weight test. With these restrictions in mind, correlations were used to calculate a lower-bound estimate of the material toughness under actual service conditions. 
Two approaches which employed the results from the Charpy impact tests were used to analyze the structural integrity of the cooling coils. The first method made use of an equation and plot from the ASME Boiler and Pressure Codes to predict the lowest service metal temperature (LST) above which brittle fracture has a low probability of occurring. The second approach utilized linear elastic fracture mechanics (LEFM) to predict a critical flaw size above which brittle fracture would initiate.

The ASME Boiler and Pressure Codes addresses the issue of LST in Section III Appendices, Article R-1000. The LST is equal to the DBTT plus a correction term determined from a plot given in the appendix. The assumptions that were made are that the DBTT from the Charpy test is equivalent to the DBTT from the drop weight test, and that the cracks are propagating in an infinitely long flat plate. For piping that is less than $2.5^{\prime \prime}$ thick, the correction term was $30^{\circ} \mathrm{F}$. At temperatures above DBTT $+30^{\circ} \mathrm{F}$, brittle fracture of the cooling water pipes is not expected. The highest value for the DBTT of A 106 was $-5^{\circ} \mathrm{F}$ for the specimens from tank 48 . Therefore, the highest value for the LST is $25^{\circ}$ $\mathrm{F}$, well below the proposed minimum operating temperature of the cooling water $\left(50^{\circ} \mathrm{F}\right)$.

Piping may fracture at nominal stresses well below the yield strength due to the presence of flaws in the material. LEFM analysis calculates the critical flaw size, at a given stress, which allows unstable crack growth to initiate. The determination of whether or not there are flaws in the piping large enough to initiate cracks is significant. The small diameter, small thickness pipe would probably break instantaneously under a seismic load should the crack initiate.

Critical flaw/failure stress relationships depend upon the toughness of the material. Tough materials will support larger flaws at a given stress level than less tough materials. The toughness, represented by $\mathrm{K}_{\mathrm{Ic}}$, of A 106 was estimated from a correlation by Corten and Sailors ${ }^{9}$ which relates the impact energy $(\mathrm{CVN})$ to $\mathrm{K}_{\mathrm{Ic}}$.

$$
\mathrm{K}_{\mathrm{Ic}}=15.5 \sqrt{\mathrm{CVN}}
$$

At $50^{\circ} \mathrm{F}$ impact energies were in the upper shelf region. The average USE for all the sub-size specimen tests was calculated and then multiplied by the fracture area to determine CVN. Given that CVN was 
$10.8 \mathrm{ft}-\mathrm{lbs}, \mathrm{K}_{\mathrm{Ic}}$ was determined to be $51 \mathrm{ksi} \sqrt{\mathrm{in}}$.. Since the CVN's measured at this temperature were low due to incomplete fracture, the calculated toughness underestimates the actual toughness. Therefore, the critical flaw calculations will also underestimate the critical flaw length for crack growth initiation making the results conservative. Pipe failure during a seismic event is most likely to occur at a circumferential flaw due to a bending moment. Figure 9 shows the flaw appearance, the applied load and the equations for solving the critical flaw length. 10 Given that the stress on the pipes during a seismic event is $15.4 \mathrm{ksi}$ and the radius is $1.07^{\prime \prime}$, the critical flaw length, $\angle \theta$, is $116^{\circ}$ or 2.2". A flaw of this magnitude is not likely to be present on the pipes, and, therefore, no problems with crack initiation during a seismic event are predicted.

An alternate method for evaluating the material toughness was proposed by J. A. Begley. 11 The thickness requirement for plane-strain fracture toughness is given by:

$$
\text { B > } 2.5\left(\mathrm{~K}_{\mathrm{Ic}} / \sigma_{\mathrm{y}}\right)^{2}
$$

where $B$ is the specimen thickness and $\sigma_{y}$ is the yield stress. If the ratio of $B$ to the pipe wall thickness is greater than five, the pipe wall will not fracture by brittle cleavage above the DBTT regardless of the applied stress. For A 106 conservative estimates of $K_{I c}$ and $\sigma_{y}$ are $50 \mathrm{ksi} \sqrt{\text { in }}$ and $45 \mathrm{ksi}$, respectively. Substituting these numbers into the above equation and given that the pipe wall thickness is $0.154^{\prime \prime}$, the aforementioned ratio is approximately 16 . This calculation indicates that the pipe wall thickness precludes brittle fracture at temperatures above the DBTT.

\section{Metallography}

Observations of the inner and outer walls of the coils concur with previous metallographic reports on sectioned coils taken from the Tank 16 valve house. 12 The zinc coating, along with the chromated water, are effective in preventing the carbon steel pipe from corrosive attack along straight sections of pipe.

The regions beneath and next to the weld slag areas may provide a means of attack from the inner wall of the pipe. The uneven areas may develop crevices which would trap the chromated water and produce 
areas of localized attack. The lack of attack at the welded areas examined does not completely rule out this mechanism.

\section{CONCLUSIONS}

The Charpy impact tests indicate that the waste tank cooling coil material is not susceptible to brittle failure at any expected cooling water operating temperatures. Sub-size impact specimens were shown to be a more accurate predictor of the DBTT for the cooling coils than the full-size specimens. The highest DBTT for any of the tank specimens was $-5^{\circ} \mathrm{F}$ and, with the addition of a $30^{\circ} \mathrm{F}$ safety factor, the minimum safe operating temperature was calculated to be $25^{\circ} \mathrm{F}$. The critical flaw size for fracture initiation during a seismic event was calculated to be $2.2^{\prime \prime}$.

Visual observations of the inner and outer walls revealed no localized attack or excessive wall thinning. Weld burn-through at the pipe fittings resulted in melting of the zinc coating on the inner wall. As a result slag built up around the weld and there was chipping of the zinc coating. There may be a potential for crevice attack in the slag area and beneath the chipped coating.

\section{FUTURE WORK}

The future work on this program includes further investigation of the mechanism for cooling coil failures. Electrochemical tests are being performed to investigate the susceptibility of A 106 to pitting in the concrete roof environment. Partial immersion coupon tests are also being performed in simulated waste tank environments to determine if pitting of A 106 occurs in the vapor space area of the tank. These experiments are expected to be complete by January 1993.

\section{REFERENCES}

1. R. S. Ondrejcin and G. E. Mertz to T. C. Hsu, "Nuclear Waste Storage Tanks Minimum Safe Cooling Coil Temperature", SRL-MTS-910122, July 16, 1991.

2. E. G. Estochen to T. C. Hsu, "Waste Tank Cooling Coil Analysis", EPD-SE-91-0170-63, June 25, 1991. 
3. R. S. Ondrejcin, "Investigation of Cooling Coil Corrosion in Radioactive Waste Storage Tanks", DP-1425, January 1977.

4. G. E. Lucas, Metallurgical Transactions A, 21 A, May 1990, pp.1105-1119.

5. R. N. Wright, in "Toughness of Ferritic Stainless Steels", ASTM STP 706, R. A. Lula ed., A merican Society for Testing Materials, 1980, pp. $2-33$.

6. Cotton, H. C., in "Practical Fracture Mechanics for Structural Steel", M. O. Dobson ed., United Kingdom Atomic Energy Authority, 1969, p. q36.

7. W. A. Spitzig and R. J. Sober, Metallurgical Transactions, 12A, (1981).

8. G. E. Dieter, "Mechanical Metallurgy", McGraw-Hill Book Company, 1961, pp. 497-502.

9. R. H. Sailors and H. T. Corten, in 'Fracture Toughness, Proceedings of the 1971 National Symposium on Fracture Mechanics", STP 514, Part II, ASTM, Philadelphia, 1972. pp. 164-191.

10. H. Tada, P. C. Paris and G. R. Irwin, "The Stress Analysis of Cracks Handbook", Second Edition, Paris Productions Incorporated, St. Louis, MO, 1985, p. 33.2.

11. Private communication with J. A. Begley on October 7, 1992.

12. S. P. Springer, EES Area Metallurgical Report, February 8, 1979 and EES Area Metallurgical Report, April 16, 1979. 
TABLE 1

Composition of A106 Cooling Coil and Reference Materials

\begin{tabular}{|c|c|c|c|c|c|c|}
\hline Heat & $\% \mathrm{C}$ & $\% \mathrm{Mn}$ & $\% \mathrm{P}$ & $\% \mathrm{~S}$ & $\% \mathrm{Si}$ & $96 \mathrm{Fe}$ \\
\hline $\mathrm{T} 48602$ & 0.21 & 0.77 & 0.004 & 0.022 & 0.15 & $\mathrm{bal}$ \\
\hline $\mathrm{D} 46140$ & 0.22 & 0.72 & 0.004 & 0.015 & 0.16 & $\mathrm{bal}$ \\
\hline $\mathrm{L} 45685$ & 0.25 & 0.81 & 0.012 & 0.018 & 0.17 & $\mathrm{bal}$ \\
\hline L45708 & 0.23 & 0.66 & 0.008 & 0.019 & 0.16 & $\mathrm{bal}$ \\
\hline L45720 & 0.22 & 0.73 & 0.013 & 0.019 & 0.19 & $\mathrm{bal}$ \\
\hline F110 (ref.) & 0.22 & 0.92 & 0.019 & 0.014 & 0.24 & $\mathrm{bal}$ \\
\hline
\end{tabular}

TABLE 2

Physical Properties of A106 Cooling Coil and Reference Materials

\begin{tabular}{|l|l|l|l|}
\hline Heat & $\begin{array}{l}\text { Yield } \\
\text { Strength (ksi) }\end{array}$ & $\begin{array}{l}\text { Tensile } \\
\text { Strength (ksi) }\end{array}$ & $\begin{array}{l}\text { \% Elongation } \\
\text { in 2" }\end{array}$ \\
\hline T48602 & 38.7 & 67.45 & 53 \\
\hline D46140 & 45.8 & 69.55 & 58 \\
\hline L45685 & 50.0 & 76.8 & 55 \\
\hline L45708 & 46.8 & 74.4 & 50 \\
\hline L45720 & 47.5 & 73.6 & 48 \\
\hline F110 (ref.) & 57.3 & 80.2 & 43.2 \\
\hline
\end{tabular}

TABLE 3

Ductile-Brittle Transition Temperature, Upper Shelf Energy and Lowest Service Metal Temperature Results from Charpy Impact Tests

\begin{tabular}{|l|c|c|c|}
\hline \multicolumn{1}{|c|}{ Identification } & DBTT (F) & $\begin{array}{c}\text { Upper Shelf Energy } \\
\text { (ft-lbs/in 2) }\end{array}$ & LST (F) \\
\hline Tank 38 inlet & -35 & 318 & -5 \\
Tank 38 outlet & -40 & 277 & -10 \\
Tank 40 & -70 & 333 & -40 \\
Tank 48 & -5 & 318 & 25 \\
Ref. sub-size & -45 & 272 & -15 \\
Ref. full-size & 50 & 447 & 80 \\
\hline
\end{tabular}

TABLE 4

Summary of Microstructural Features

\begin{tabular}{|l|c|c|c|}
\hline Specimens & ASTM Grain Size & \% Pearlite & Vol. \% Inclusions \\
\hline Tank 38 inlet & 8.0 & 23.6 & .011 \\
Tank 38 outlet & 8.0 & 24.1 & .0585 \\
Tank 40 & 9.5 & 15.5 & .0424 \\
Tank 48 & 8.0 & 22.8 & .004 \\
Ref. sub-size & 6.5 & 20.5 & .0565 \\
Ref. full-size & 6.5 & 22.2 & .0629 \\
\hline
\end{tabular}




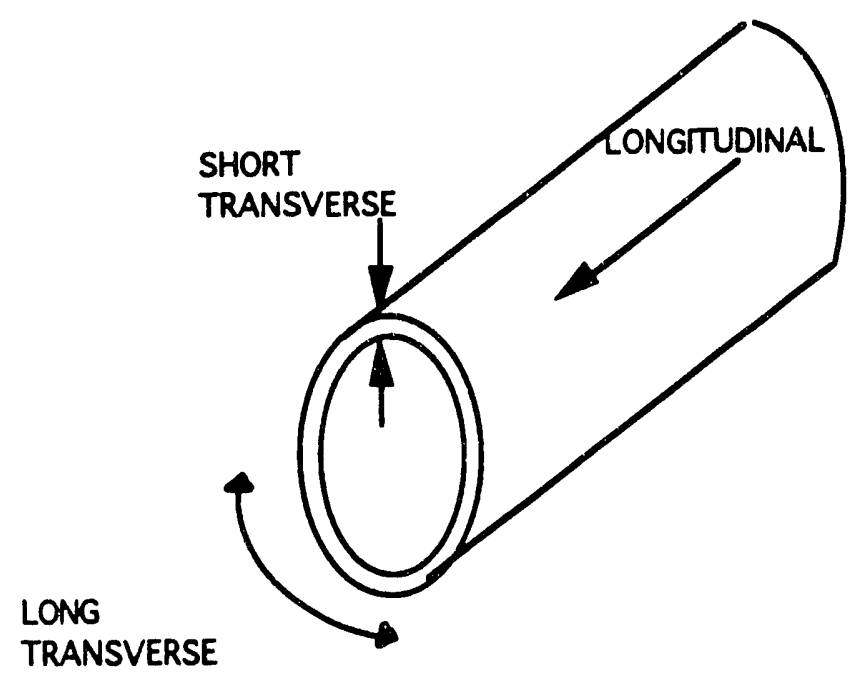

(a)

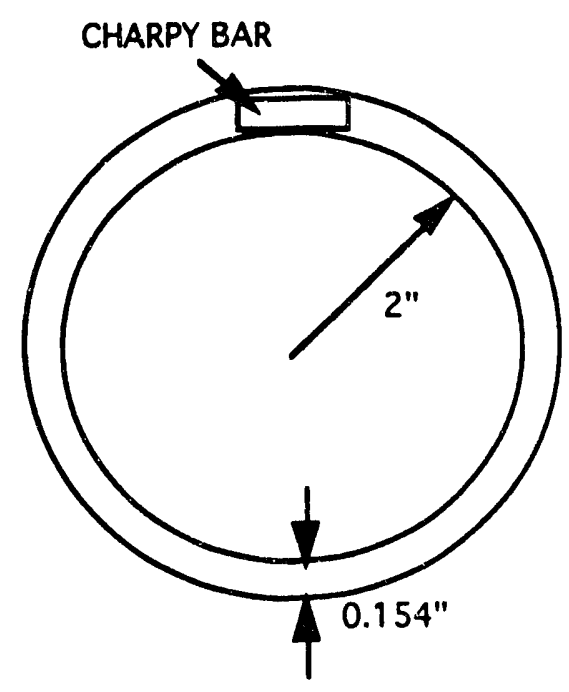

(b)

Figure 1. Schematic Drawings of a) Cooling Coil Pipe Showing Orientation Directions And b) The Orientation of The Charpy Bar In The Cooling Coil. 
Page 16 of 22

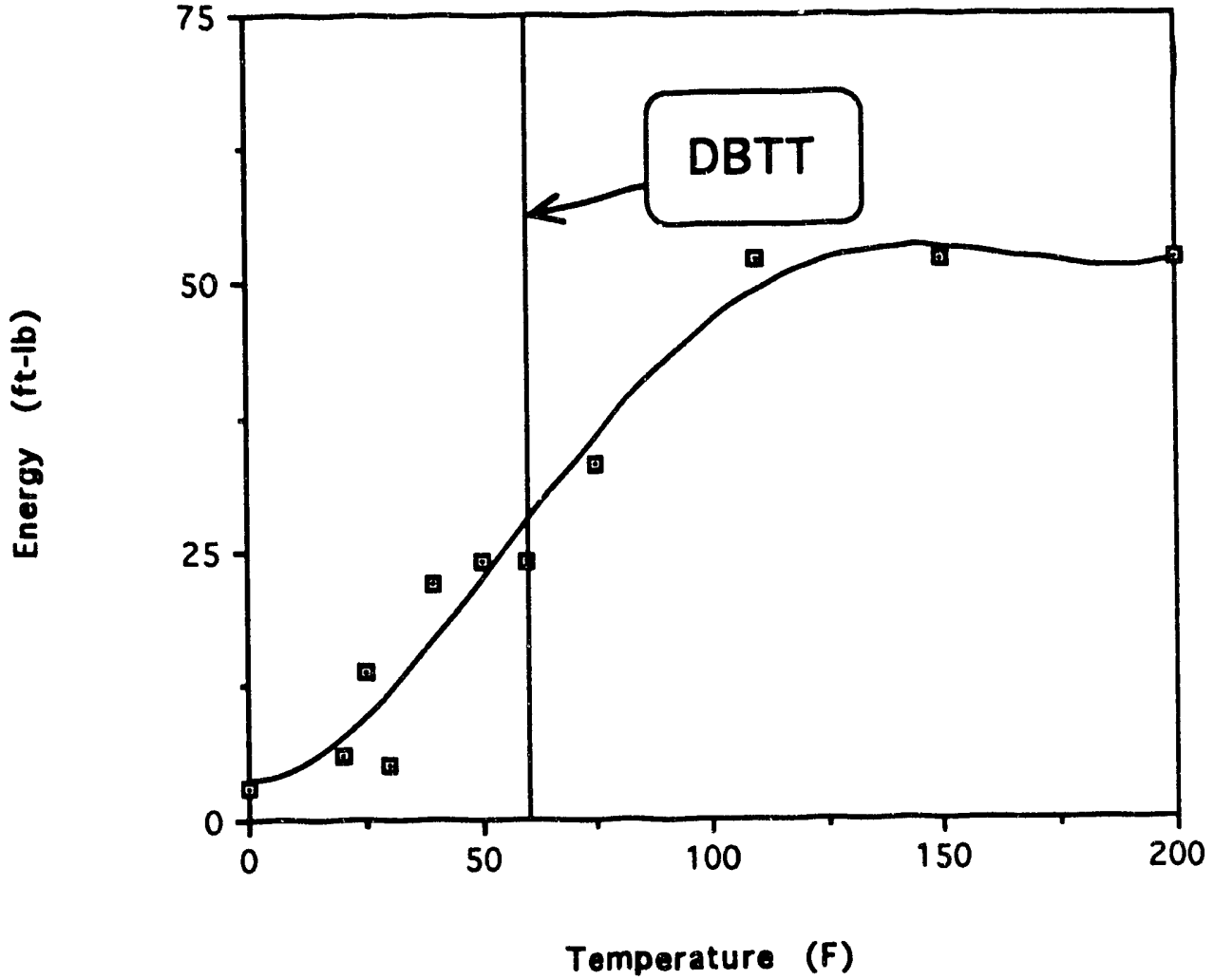

Figure 2. Schematic Diagram Of Charpy Impact Data Arid Determination of The Ductile To Brittle Transition Temperature (DBTT). 


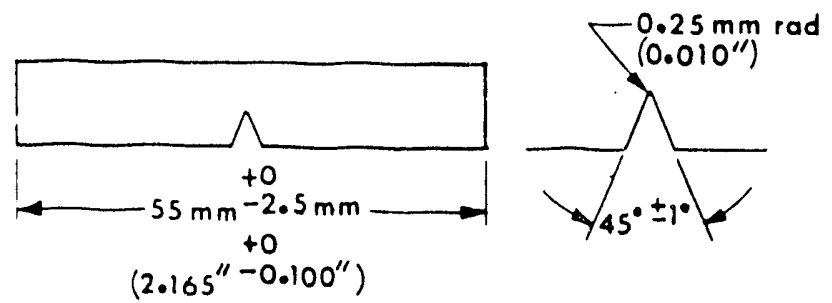

(a)

$3 \mathrm{~mm}\left(0.118^{\circ}\right)$

(b)

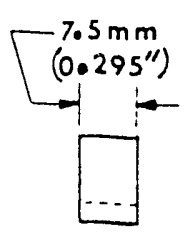

(c)

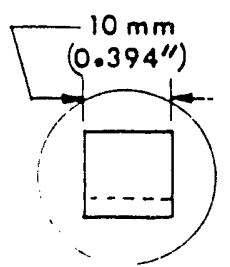

(d)

Figure 3. ASTM Dimensions For Charpy Impact Specimens For a) Length of Specimen And Notch Aculty, b) Sub-Size, c) MEA and d) Full-Size. 


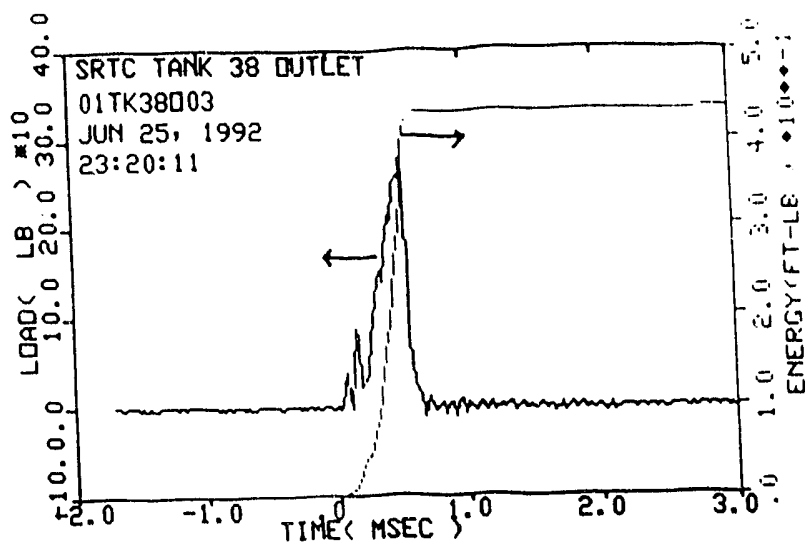

(a)

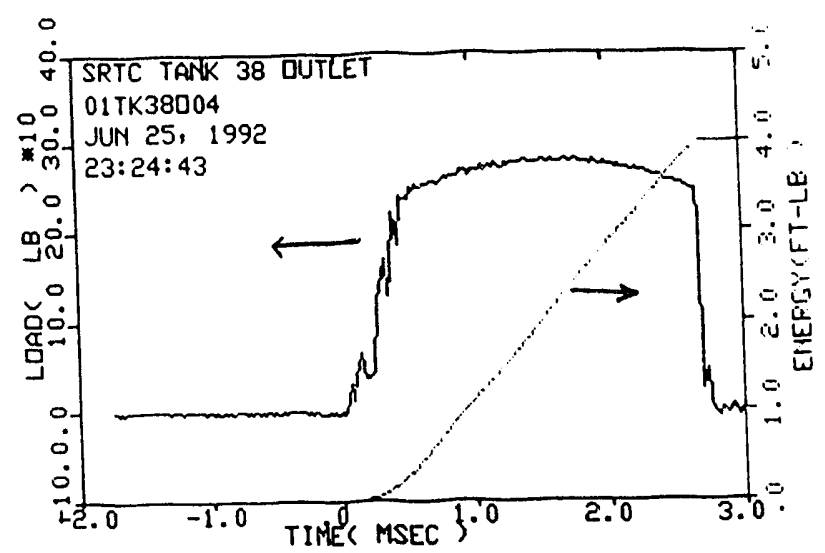

(b)

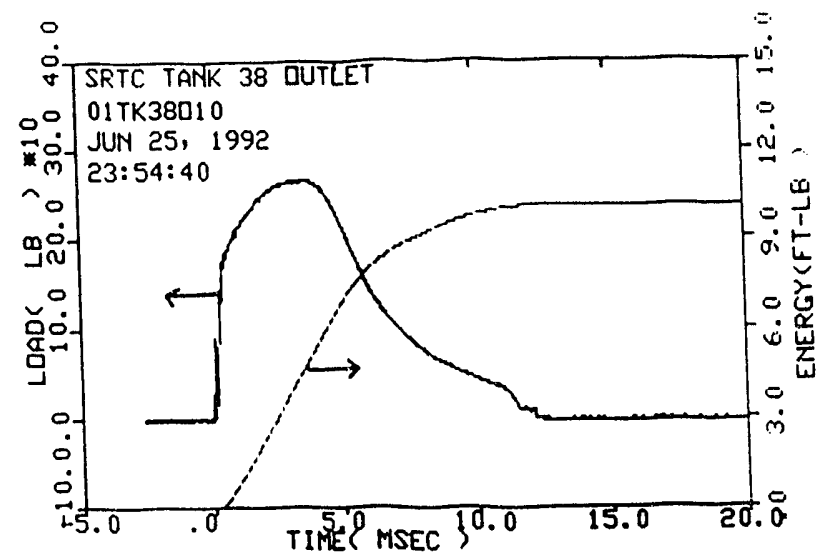

(c)

Figure 4. Load vs. Time Data During Charpy Impact Test On Tank 38 Outlet Specimens At a) $-175^{\circ} \mathrm{F}$, b) $-100^{\circ} \mathrm{F}$, and c) $50^{\circ} \mathrm{F}$. 


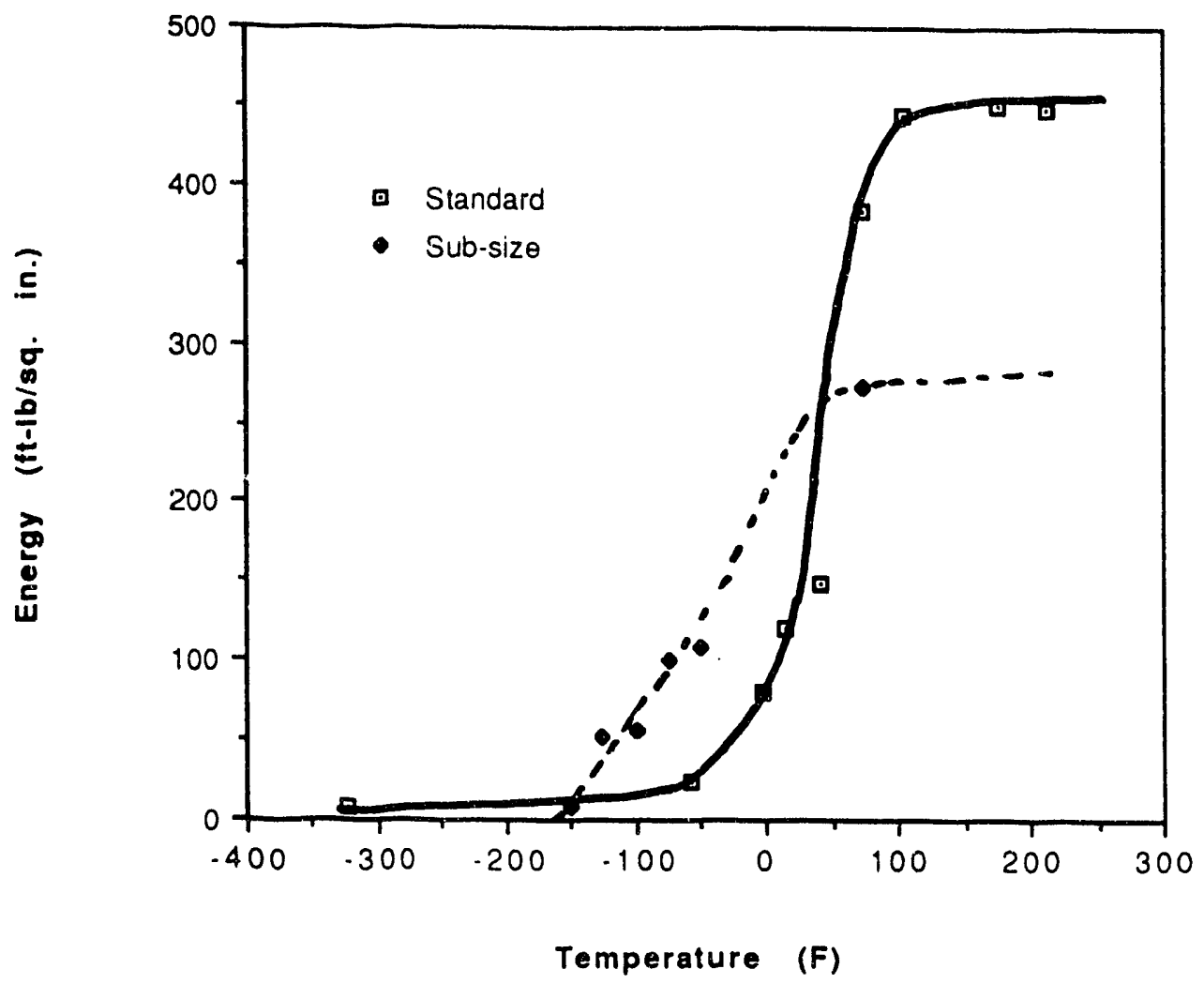

Figure 5. Energy vs. Temperature For Full-Size And SubSize Reference Specimens. 


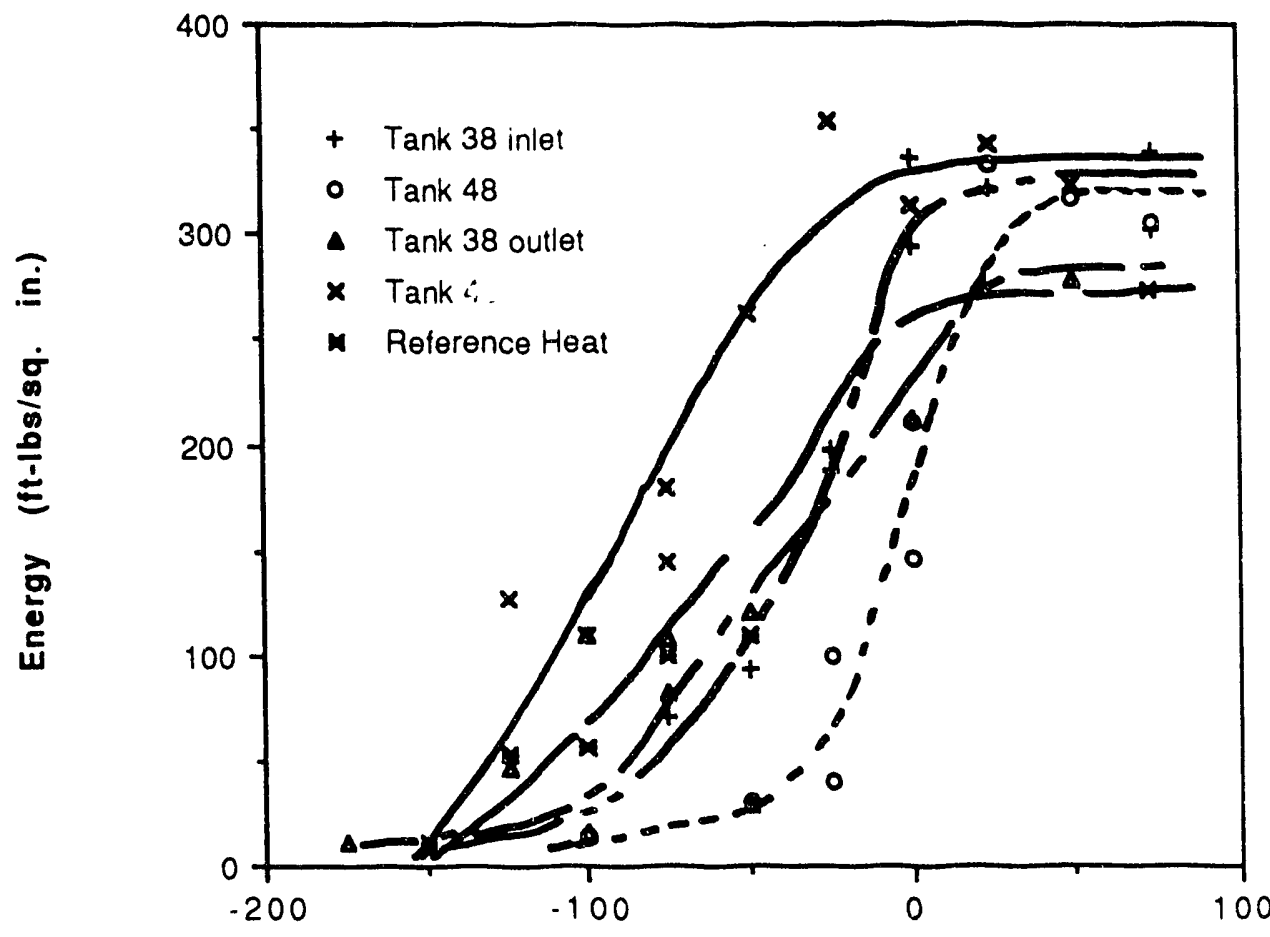

Temperature (F)

Figure 6. Energy vs. Temperature For Sub-Size Tank And Reference 


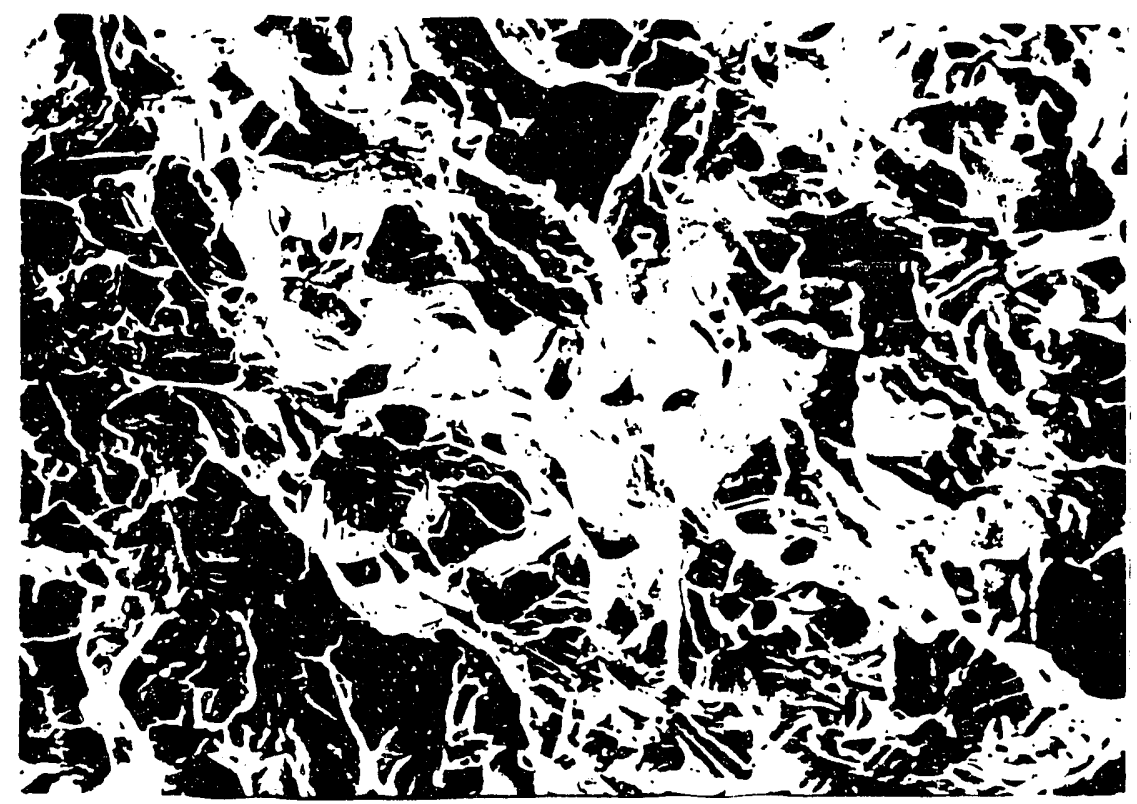

Figure 7. Charpy Specimen Fracture Surface of Specimen From Tank 38 Inlet Tested At $-100^{\circ} \mathrm{F}$ (500x).

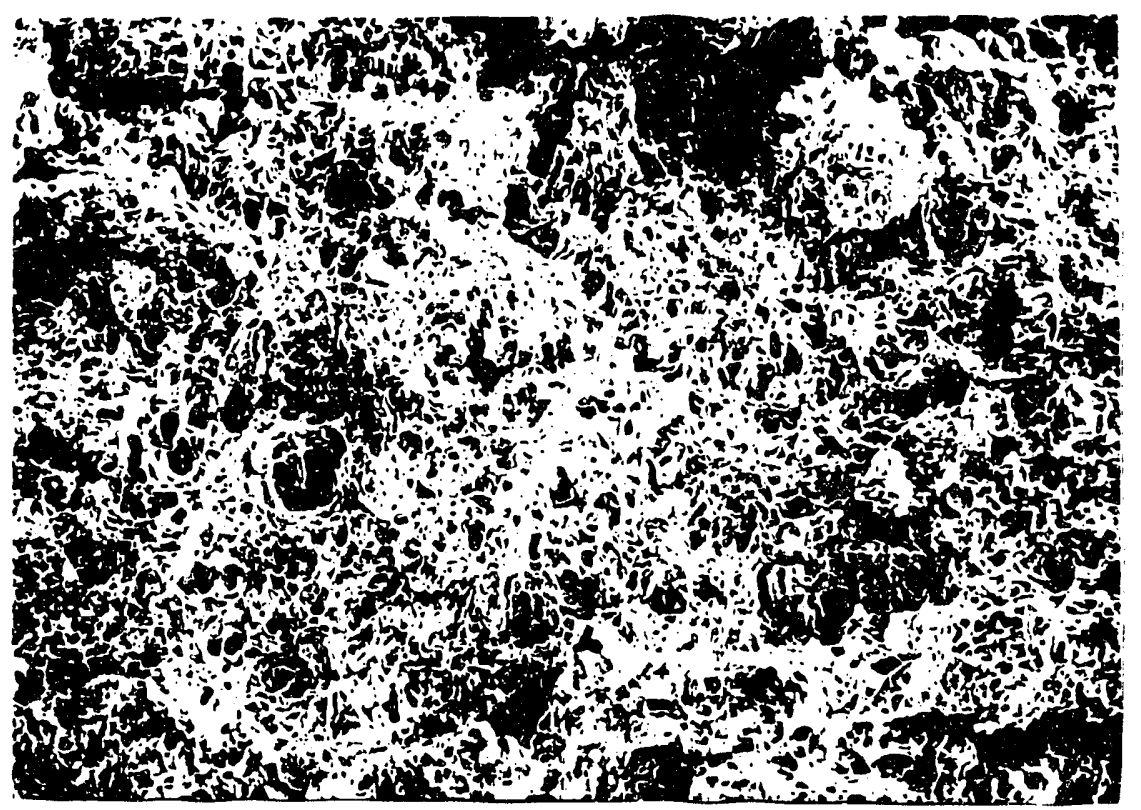

Figure 8. Charpy Specimen Fracture Surface Of Specimen From Tank 38 Inlet Tested At $25^{\circ} \mathrm{F}(100 \mathrm{x})$. 
WSRC-TR-92 444

UNCLASSIFIED

Page 22 of 22

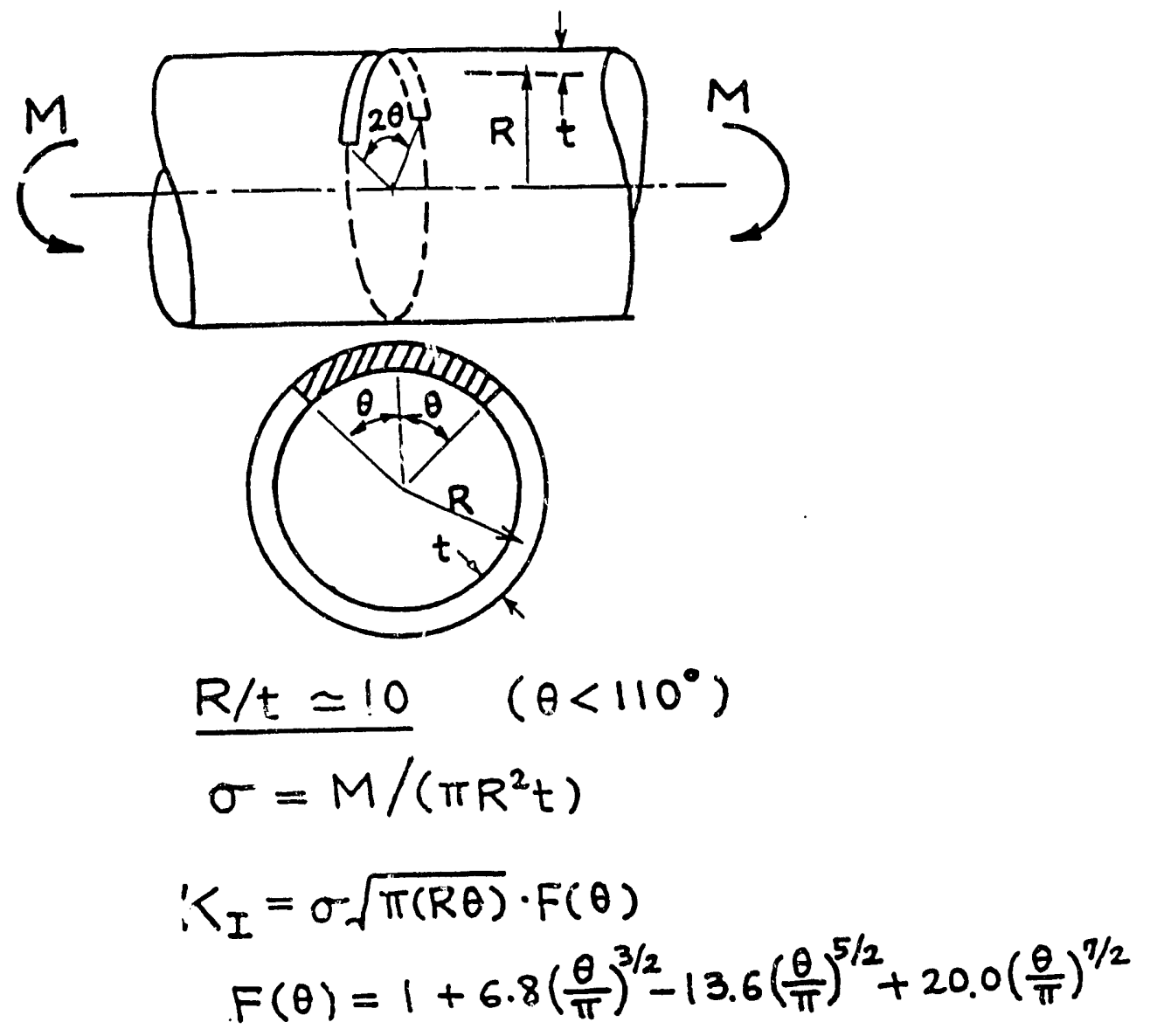

Figure 9. LEFM Analysis For A Circumferential Flaw Subjected To A Seismic Bending Moment. 

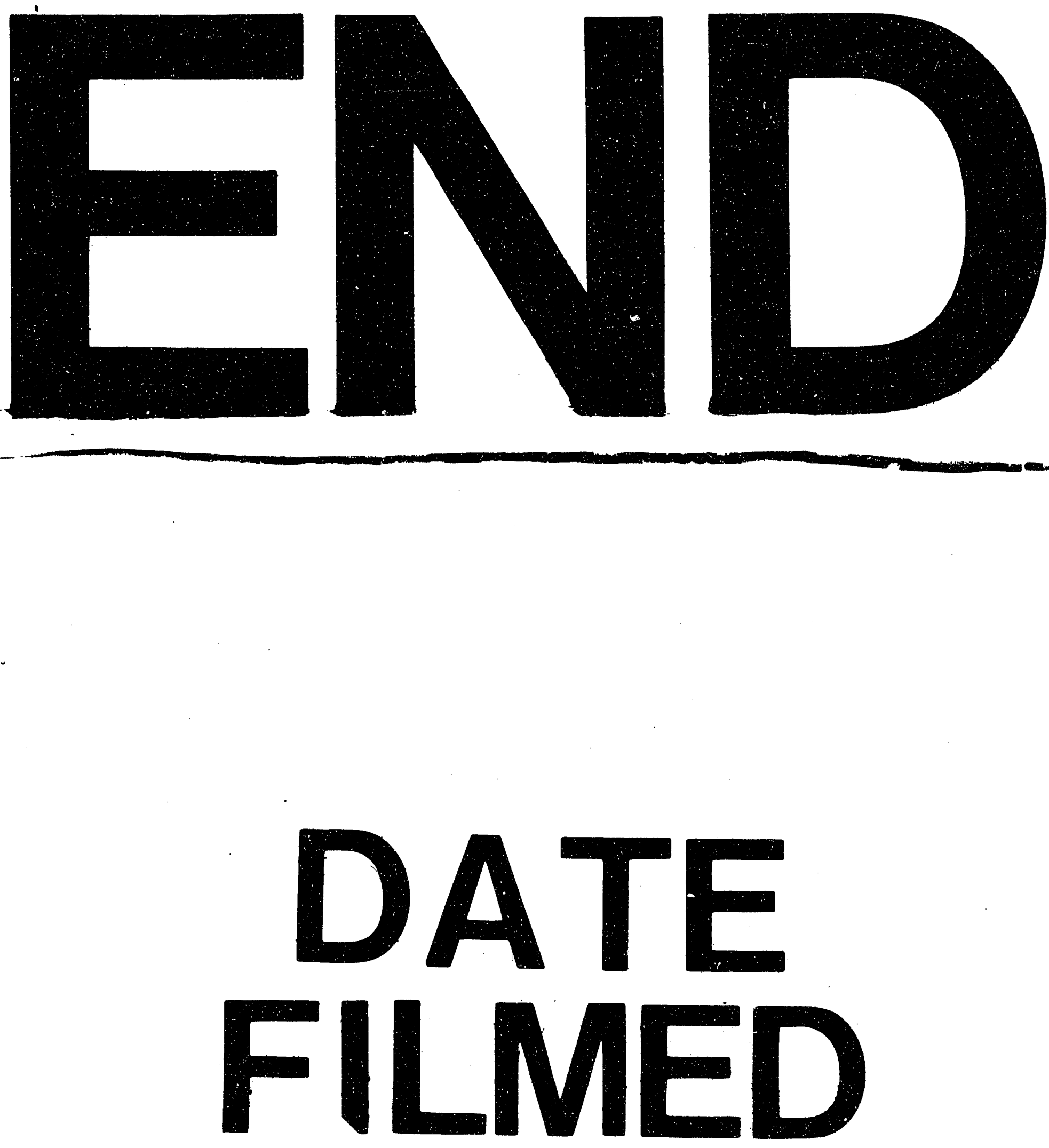

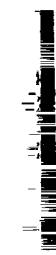

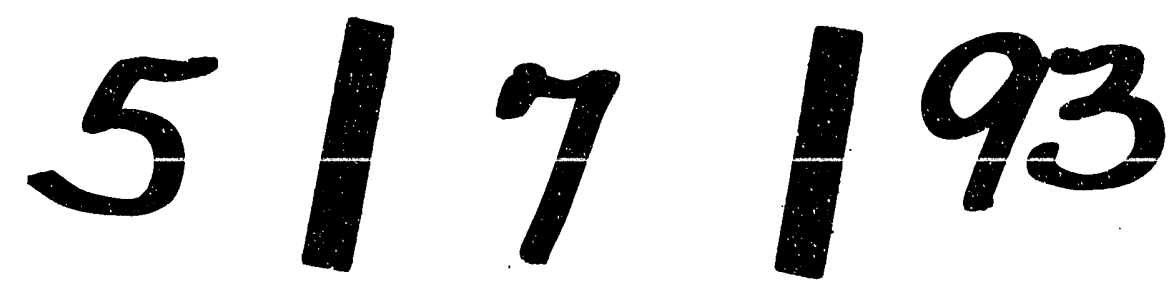


